\author{
ANETA PALECZNA \\ https://doi.org/10.33995/wu2020.4.7
}

\title{
Glosa do uchwały Składu Siedmiu Sędziów Sądu Najwyższego - Izba Kontroli Nadzwyczajnej i Spraw Publicznych z dnia 22 października 2019 roku, sygn. I NSNZP 2/19 1
}

Glosa stanowi próbę analizy granic kompensacji szkody na gruncie uchwały Sqdu Najwyższego z 22 października 2019 r. (I NSNZP 2/19). Na tym tle w sposób szczególny zarysowuje się zagadnienie zadośćuczynienia za uszczerbek na zdrowiu poniesiony przez osoby bliskie oraz problematyka konstruowania przedmiotu ochrony cywilnoprawnej w postaci więzi rodzinnej. Zgodnie z tq uchwała osobie bliskiej poszkodowanego nie przysługuje zadośćuczynienie za doznanq krzywdę w sytuacji naruszenia więzi rodzinnej na skutek uszczerbku na zdrowiu bezpośrednio poszkodowanego. Wocenie Sqqu Najwyższego więź rodzinna nie jest dobrem osobistym i ze swojej natury ma charakter relatywny. Choć katalog dóbr osobistych na gruncie rodzimego prawodawstwa jest otwarty, nie oznacza to, że zawsze subiektywne i nieskonkretyzowane więzi międzyludzkie będq zasługiwały na ochronę prawnq. Wreszcie, poziom satysfakcji z życia rodzinnego nie powinien uzasadniać przyznania zadośćuczynienia za szkodę niemajatkowa. Uchwała Sqdu Najwyższego pozostaje także istotna na tle uchwały Sqdu Najwyższego z 27 marca 2018 roku, w której Sqd Najwyższy wyraził całkowicie odmienne zapatrywanie i uznał, że osoby bliskie mogq żqqdać zadośćuczynienia za doznanq krzywdę wskutek uszczerbku na zdrowiu poszkodowanego.

Słowa kluczowe: dobra osobiste, szkoda pośrednia, więź rodzinna, granice kompensacji szkody, krzywda.

1. Problematyka dochodzenia zadośćuczynienia za uszczerbek na zdrowiu poniesiony przez osobę bliską na podstawie art. 23-24 k.c. ${ }^{2}$ w zw. z art. 448 k.c. była już przedmiotem zainteresowania

1. Legalis $\mathrm{nr} 2236263$.

2. Ustawa z 23.04.1964 r. - Kodeks cywilny (Dz. U. 1964 nr 16, poz. 93). 
sądów wyższych instancji ${ }^{3}$, a nawet Sądu Najwyższego ${ }^{4}$. Sprawa zwieńczona komentowanym orzeczeniem należy jednak do wyjątkowych, ponieważ Sąd Najwyższy przesądził, że osobie bliskiej poszkodowanego, który na skutek deliktu doznał ciężkiego i trwałego rozstroju zdrowia, nie przysługuje zadośćuczynienie pieniężne na podstawie art. 448 k.c., co odbiega od dotychczasowego stanowiska prezentowanego w orzecznictwie. W konsekwencji obecnie w obrocie prawnym funkcjonują dwie uchwały ${ }^{5}$ Sąu Najwyższego o wzajemnie sprzecznej treści, co nie przeszło bez echa i wzbudziło zainteresowanie przedstawicieli nauki prawa i przedstawicieli praktyki ${ }^{6}$. Istota sprawy przedstawionej do rozpoznania Sądowi Najwyższemu sprowadzała się do poszukiwania odpowiedzi na pytanie, czy osoba bliska jest uprawniona do dochodzenia roszczeń z tytułu uszczerbku na zdrowiu doznanego przez poszkodowanego na skutek deliktu. W razie udzielenia odpowiedzi twierdzącej na to pytanie konieczne pozostaje ustalenie podstawy prawnej, w oparciu o którą osoba pośrednio poszkodowana mogłaby występować z żądaniem. Odpowiedź na sformułowane zagadnienie ma istotne znaczenie nie tylko dla praktyki, ale również dla istoty i zakresu odpowiedzialności odszkodowawczej, która stanowi fundament prawa cywilnego. To tym bardziej skłania do podjęcia trudu glosatorskiego.

2. Do sformułowania zagadnienia prawnego, przedstawionego na podstawie art. $398^{17} \S 1$ k.p.c. oraz podjęcia uchwały przez Sąd Najwyższy prowadził następujący stan faktyczny: powód doznał poważnego uszczerbku na zdrowiu na skutek udaru mózgu. Do uszczerbku doszło ze względu na zbyt późną diagnozę poszkodowanego przez publiczny zakład opieki zdrowotnej. Obok poszkodowanego, pacjenta, powodami w sprawie byli jego była małżonka oraz syn. Sąd I instancji przyjał, że zaistniały stan faktyczny uzasadnia zasądzenie na rzecz poszkodowanego zadośćuczynienia oraz odszkodowania, w tym w formie miesięcznej renty, a także ustalenie odpowiedzialności na przyszłość za wszelkie szkody związane z nieprawidłowościami, jakich dopuścił się personel pozwanego publicznego zakładu opieki zdrowotnej, o ile takie się ujawnią. W jego ocenie rozstrój zdrowia poszkodowanego powoda spowodował trwałe naruszenie relacji rodzinnych i więzi bliskości pomiędzy małżonkami oraz pomiędzy powodem i jego synem, co uzasadnia żądanie w oparciu o art. 448 k.c. W wyniku rozpoznania apelacji pozwanego Sąd Apelacyjny zmienił zaskarżony wyrok w ten sposób, że oddalił powództwo w części zasądzającej zadośćuczynienie na rzecz byłej żony i syna bezpośrednio poszkodowanego. Są drugiej instancji stanął na stanowisku, że wyłącznie śmierć członka rodziny może naruszyć dobra jego najbliższych. W związku z tym w sprawie, będacej przedmiotem rozpoznania, więzi rodzinne zostały zachowane, chociaż nie na takim poziomie satysfakcji, jak przed zdarzeniem.

3. Odnosząc się w pierwszej kolejności do trafności rozstrzygnięcia, należy zaaprobować sentencję oraz jego motywy. Skoro prawodawca wprost reguluje przypadki, w których istnieje prawo

3. Tak m.in. wyrok SA we Wrocławiu z 17 września 2013 r., sygn. I ACa 840/13, niepubl.; wyrok SA w Białymstoku z 12 czerwca 2019 r., sygn. I ACa 187/19, Legalis nr $223875 ?$.

4. Wyroki SN z 9 sierpnia 2016 r., sygn. II CSK 719/15, Legalis nr 1507564 i z 31 maja 2019 r., sygn. IV CSK 141/18, Legalis nr 1973118.

5. Uchwała SN z 22 października 2019 r., sygn. I NSNZP 2/19, Legalis nr 2236263 i uchwała SN z 27 marca 2018 r., sygn. III CZP 60/17, Legalis nr 178192?.

6. Wniosek Rzecznika Finansowego z 13 grudnia 2019 r., https://rf.gov.pl/pdf/SN_wniosek_stany_wegetatywne. pdf [dostęp: 4.09.2020]. 
do żądania rekompensaty za „szkodę pośrednia”, to co do zasady w polskim systemie prawnym poszkodowanym jest osoba, która doznała szkody podlegającej naprawieniu i przeciwko której było skierowane zdarzenie sprawcze? . Nie ulega także watpliwości, że art. 448 k.c. w obecnym brzmieniu nie daje podstawy do przyznania zadośćuczynienia osobie bliskiej z tytułu poniesionego uszczerbku na zdrowiu ${ }^{8}$.

Model regulacyjny przyjęty w Kodeksie zobowiązań i realizowany w ramach Kodeksu cywilnego zakłada - jak trafnie zauważył Sąd Najwyższy w glosowanym orzeczeniu - kompensatę jedynie w przypadkach przewidzianych w ustawie. Dwie kwestie zaznaczone w uzasadnieniu orzeczenia wymagaja jednak dodatkowego komentarza. Po pierwsze, do 2008 roku w zasadzie nie przyznawano zadośćuczynienia pieniężnego za krzywdę powstałą na skutek śmierci członka rodziny czy, tym bardziej, doznania uszczerbku na zdrowiu ${ }^{9}$. Wprowadzenie do Kodeksu cywilnego przepisu art. $446 \S 4^{10}$ stanowi potwierdzenie istnienia podziału na pośrednio i bezpośrednio poszkodowanych. Przy czym w prawie polskim istniały wówczas co najmniej trzy podstawy normatywne umożliwiające uwzględnienie roszczenia o zadośćuczynienie z tytułu śmierci najbliższego członka rodziny, to jest: 446 § 3 k.c., 448 k.c. albo 445 k.c. ${ }^{11}$. Gdyby nie wprowadzono art. $446 \S 4$ k.c., roszczenia tego mógłby dochodzić każdy, a nie tylko najbliższy członek rodziny ${ }^{12}$. Co więcej, po nowelizacji Kodeksu cywilnego Sąd Najwyższy przesądził, że najbliższemu członkowi rodziny zmarłego przysługuje na podstawie art. 448 k.c. w zw. z art. 24 § 1 k.c. zadośćuczynienie pieniężne za doznaną krzywdę, gdy śmierć nastapiła na skutek czynu niedozwolonego, który miał miejsce przed 3 sierpnia 2008 roku $^{13}$. Stanowisko to spotkało się jednak z krytyką w piśmiennictwie ${ }^{14}$.

Po drugie, co dostrzegł także Sąd Najwyższy, nawet w prawodawstwie państw o tradycji germańskiej rozszerzono możliwość kompensacji szkody. Roszczenia z tytułu poważnego uszkodzenia ciała albo rozstroju zdrowia bezpośrednio poszkodowanego oparte są na przepisach ogólnych odpowiedzialności cywilnej (klauzuli generalnej - art. 1382 francuskiego kodeksu cywilnego),

7. E. Bagińska, Dopuszczalność dochodzenia przez osoby bliskie zadośćuczynienia w zwiqzku z doznaniem poważnej szkody na osobie przez bezpośrednio poszkodowanego, „lustitia” 2016, nr 2, s. 70; M. Owczarek, Problem bezprawności względnej w systemie odpowiedzialności deliktowej, „Palestra” 2004, nr 5-6[55?558], s. 41; M. Wałachowska, Roszczenie o zadośćuczynienie pieniężne za zerwanie więzi rodzinnych w razie doznania przez osobę bliska poważnego uszczerbku na zdrowiu, „Przegląd Sądowy” 2017, nr 9, s. 17; M. Wałachowska, Glosa do wyroku Sqdu Najwyższego z 14.01.2010 r., IV CSK 307/09, „Orzecznictwo Sqdów Polskich" 2011, nr 2, poz. 15, s. 94; L. Bosek, W sprawie kwalifikacji więzi rodzinnej jako dobra osobistego (uwagi krytyczne na tle aktualnego orzecznictwa Sqdu Najwyższego), „Forum Prawnicze” 2015, s. 16.

8. M. Gąska, Więź rodzinna - refleksje nad charakterem dobra oraz dopuszczalnościq i sposobami kompensacji krzywdy wywołanej jego naruszeniem, „Forum Prawnicze” 2018, s. 30.

9. M. Wałachowska, Roszczenie o zadośćuczynienie..., nr 9, s. 17.

10. Ustawa o zmianie ustawy - Kodeks cywilny oraz niektórych innych ustaw z dnia 30 maja 2008 roku [Dz. U. nr 116, poz. 731].

11. J. Sadomski, M. Wild, Zadośćuczynienie za śmierć osoby najbliższej w orzecznictwie sqdów powszechnych, „Prawo w Działaniu. Sprawy Cywilne” 2012, nr 12, s. 60; por. wyrok Sądu Najwyższego z 14 stycznia 2010 r., sygn. IV CSK 307/09, Legalis nr 254072.

12. Por. uchwała SN z 22 października 2010 r., sygn. III CZP 76/10, Legalis nr 254081.

13. Uchwała SN z 22 października 2010 r., sygn. III CZP 76/10, Biul. SN 2010, nr 10, poz. 11; wyrok SN z 25 czerwca 2020 r., sygn. II CSK 535/18, LEX nr 3033908.

14. M. Orlicki, 0 możliwości dochodzenia roszczeń o zadośćuczynienie za śmierć najbliższego członka rodziny zmarłego przed dniem 3 sierpnia 2018 r., „Prawo Asekuracyjne” 2013, nr 4, s. 19. 
rozszerzających interpretację obowiązujących przepisów albo na analogii (art. 23 w zw. z art. 24 w zw. z art. 448 k.c.), ale również na szczególnej ustawowej podstawie roszczenia (art. 180 ust. 2, 3 i 4 słoweńskiego kodeksu zobowiązań ${ }^{15}{ }^{16}$. Nie można przy tym tracić z pola widzenia, że istotna rolę w dochodzeniu roszczeń ma orzecznictwo (Francja, Austria, Włochy, Hiszpania). W krajach pozostających pod wpływem tradycji romańskiej i germańskiej judykatura dopuszcza żądanie o zadośćuczynienie w ściśle oznaczonych sytuacjach ${ }^{17}$. W austriackim systemie prawnym kształt roszczenia o odszkodowanie dla osób pośrednio poszkodowanych (Trauerschmerzengeld) jest dziełem orzecznictwa, w świetle którego prawo to przysługuje ograniczonemu kręgowi poszkodowanych. Źródłem szkody może być sam fakt doznania uszczerbku przez bezpośrednio poszkodowanego, uzyskanie o tym informacji czy obserwacja zdarzenia szkodzącego. W niektórych systemach prawnych konieczne jest, aby uszczerbek był poważny i trwały (np. Włochy), w innych zaś nie jest to warunek konieczny (np. Francja) ${ }^{18}$. Kierunek orzeczniczy przyjęty w krajach Europy Zachodniej oraz tendencje prawodawcze potwierdzają ogólną formułę naprawienia szkody niemajattkowej wyrządzonej na skutek naruszenia dóbr osobistych ${ }^{19}$.

4. Problematyka zadośćuczynienia za krzywdę poniesioną na skutek zerwania więzi rodzinnej rozumianej jako dobro osobiste stanowiła przedmiot licznych wypowiedzi w orzecznictwie, tak sądów powszechnych ${ }^{20}$, jak i Sądu Najwyższego ${ }^{21}$. Przy czym orzeczenia te zwykle zapadały w stanie faktycznym, w którym osoba bliska zmarła, nie zaś doznała uszczerbku na zdrowiu. Obecnie można dostrzec wzrost liczby powództw o zapłatę zadośćuczynienia na podstawie art. 448 k.c. z tytułu zerwania więzi rodzinnej na skutek doznania przez najbliższego członka rodziny rozstroju zdrowia albo uszkodzenia ciała.

Zwolennicy poglądu o dopuszczalności dochodzenia roszczeń z tytułu zerwania więzi rodzinnych w przypadku szkody na osobie doznanej przez najbliższego członka rodziny wskazuja, że intensywność cierpień w takim przypadku może być nawet większa niż w razie śmierci osoby bliskiej ${ }^{22}$. Innym powoływanym argumentem jest konieczność zapewnienia ochrony więzi rodzinnej jako wartości chronionej na poziomie konstytucyjnym. Z aksjologicznego punktu widzenia trudno bowiem zaakceptować przyznanie zadośćuczynienia z tytułu śmierci osoby bliskiej i równocześnie

15. http://www2.gov.si/zak/Zak_vel.nsf/7e8891d494d7669fc1256616002db47b/c12563a400338836c1256 adb002917dd?OpenDocument [dostęp: 20.08.2020]; zob. także: M. Wałachowska, Wynagrodzenie szkód deliktowych doznanych przez pośrednio poszkodowanych, Wolters Kluwer, Warszawa 2014, s. 386-398.

16. E. Bagińska, Kompensacja krzywdy osób najbliższych w razie poniesienia przez poszkodowanego ciężkiego uszczerbku na zdrowiu - przeglad rozwiqzań europejskich, [w:] Rozprawy z prawa prywatnego. Księga jubileuszowa dedykowana Profesorowi Wojciechowi Popiołkowi, [red.] M. Jagielska, M. Pazdan, E. Rott-Pietrzyk, M. Szpunar, Wolters Kluwer, Warszawa 2017, s. 634 i nast.

17. E. Bagińska, op. cit., s. 634-635.

18. M. Wałachowska, op. cit., s. 386-398.

19. Zob. szerzej: E. Bagińska, op. cit., s. 640.

20. Wyroki SA w Gdańsku z 23 września 2005 r., sygn. I ACa 554/05, Legalis nr 77703 i z 14 grudnia 2007 r., sygn. I ACa 1137/07, Legalis nr 287203.

21. Wyrok SN z 14 stycznia 2010 r., sygn. IV CSK 307/09, Legalis nr 254072; uchwała SN z 22 października 2010 r., sygn. III CZP 76/10, Legalis nr 254081; postanowienie SN z 27 czerwca 2014 r., sygn. III CZP 2/14, Legalis nr 994661.

22. Wyrok SA we Wrocławiu z 17 września 2013 r., sygn. I ACa 840/13, niepubl. 
odmówienie tej ochrony, gdy osoba bliska dozna uszczerbku na zdrowiu. Zarówno w jednej, jak i w drugiej sytuacji dochodzi do naruszenia tego samego dobra osobistego, zaś różnica w zakresie intensywności naruszenia dobra osobistego może co najwyżej wpłynąć na wysokość zadośćuczynienia ${ }^{23}$. Wreszcie - wskazuje się, że skoro ochronie podlega prawo do kultu pamięci po osobie zmarłej, to nieuzasadnione byłoby odmówienie ochrony osobom najbliższym poszkodowanego, który doznał uszczerbku na zdrowiu ${ }^{24}$.

Oceniając naruszenie więzi rodzinnej (prawa do życia w rodzinie ${ }^{25}$, prawa do niezakłóconego życia rodzinnego ${ }^{26}$, prawa do spokoju życia rodzinnego ${ }^{27}$, prawa do utrzymania więzi ${ }^{28}$, prawa do życia w związku małżeńskim, posiadania ojca i życia w pełnej rodzinie ${ }^{29}$ ) z perspektywy ochrony dóbr osobistych dostrzec należy charakter tej więzi, która wyklucza uznanie jej za indywidualną, niemajątkową wartość ściśle związaną z jednostką ludzką i z psychofizyczną naturą tej jednostki. Podzielając pogląd wyrażony przez Sąd Najwyższy w glosowanym orzeczeniu, należy uznać, iż więź rodzinna stanowi konglomerat, mozaikę dynamicznych i podlegających nieustannym zmianom stosunków (sił) pomiędzy dwiema osobami - bezpośrednio poszkodowanym i osobą bliską (pośrednio poszkodowana). Uczucia pomiędzy ludźmi, w tym pomiędzy najbliższymi krewnymi, są wypadkową wielu czynników i zależą w szczególności od ich stosunków z pozostałymi członkami rodziny, od fizycznej bliskości lub fizycznego dystansu czy cech charakteru ${ }^{30}$. Wartości niemajątkowe, które decydują o odrębności i indywidualności danej osoby, nie wynikają z faktu pozostawania albo niepozostawania w pewnej grupie ludzi ${ }^{31}$. Uczucia podlegają dynamicznym zmianom, moga naprzemiennie osłabiać się, wygasać oraz pogłębiać, są tak niejednoznaczne i niedookreślone, że nie zawsze należy upatrywać w nich przedmiot ochrony prawnej ${ }^{32}$. Dla jednej ze stron więź ta może być silna, pełna emocji i trwała, zaś dla drugiej, więź ta może być niezadowalająca i powierzchowna. Można zatem podzielać pogląd wyrażany w piśmiennictwie, zgodnie z którym uznawanie więzi rodzinnej za dobro osobiste godzi w konstrukcję dobra osobistego ${ }^{33}$.

23. K. Osajda, Zadośćuczynienie za doznanie przez bliskiego uszczerbku na zdrowiu wskutek wypadku, „Państwo i Prawo" 2016, nr 1, s. 7 ?

24. Wyrok SN z 9 sierpnia 2016 r., sygn. II CSK 719/15, Legalis nr 1507564.

25. Wyrok SN z 15 marca 2012 r., sygn. I CSK 314/11, LEX nr 1164718.

26. Wyrok SA w Gdańsku z 23 września 2005 r., sygn. I ACa 554/05, Legalis nr 77703.

27. Wyrok SA w Warszawie z 8 stycznia 2016 r., sygn. I ACa 442/15, LEX nr 1979320.

28. Wyrok SN z 14 stycznia 2010 r., sygn. IV CSK 307/09, 0SP nr 2/2011, poz. 15.

29. Wyrok SA w Gdańsku z 14 grudnia 2007 r., sygn. I ACa 1137/07, Legalis nr 287203.

30. Wyrok SA w Katowicach z 15 maja 2015 r., sygn. I ACa 131/15, Lex nr 1747245, B. Lanckoroński, Kontrowersje wokół ustalania odpowiedzialności z tytułu naruszenia więzi rodzinnych jako dobra osobistego, „Studia Prawnoustrojowe" 2019, nr 46, s. 193; W. Popiołek, Więź między osobami fizycznymi jako przedmiot ochrony cywilnoprawnej, [w:] Experientia Docet. Księga jubileuszowa ofiarowana Pani Profesor Elżbiecie Traple, [red.] P. Kostański, P. Podrecki, T. Targosz, Wolters Kluwer, Warszawa 2017, s. 1053-1054.

31. L. Bosek, op. cit., s. 9.

32. Wyrok SA w Warszawie z 6 listopada 2012 r., sygn. I ACa 428/12, LEX nr 1240248, J. Matys, Kontrowersje wokół podstaw i przesłanek zadośćuczynienia na rzecz najbliższych osób zmarłego, „Administracja Publiczna. Studia Krajowe i Międzynarodowe. Zeszyty Naukowe WSAP w Białymstoku" 2006, nr 1, s. 282, M. Wałachowska, Glosa do wyroku SN..., s. 94.

33. L. Bosek, op. cit., s. 10. 
Podkreślenia w tym miejscu wymaga, że dynamiczny ze swej istoty charakter więzi rodzinnej nie przekreśla ochrony zagwarantowanej rodzinie w Konstytucji Rzeczpospolitej Polskiej jako zasady ustrojowej oraz podstawowej konstytucyjnej regulacji prawa rodzinnego (art. 18) ${ }^{34}$. Wartość taka, jak rodzina, ma doniosłe znaczenie prawne i społeczne, ale nie oznacza to, że nie powinny być one chronione przez przepisy prawa rodzinnego, a jedynie uzupełniająco prawa cywilnego. Przy czym art. 18 Konstytucji RP nie określa praw podmiotowych przysługujących indywidualnym obywatelom ${ }^{35}$, a zatem nie może być podstawa przysługujących osobiście obywatelom roszczeń, w tym nie może być podstawą skargi konstytucyjnej ${ }^{36}$. Na ustawodawcy zwykłym spoczywa obowiązek uregulowania instytucji małżeństwa, rodziny, macierzyństwa i rodzicielstwa. Równocześnie nie każda wolność czy prawo konstytucyjne stanowi dobro osobiste na gruncie art. 23 k.c. ${ }^{37}$, a wykładnia prawa nie powinna być determinowana wyłącznie argumentami aksjologicznymi ${ }^{38}$. Wreszcie, z żadnego z przepisów Konstytucji nie wynika, że art. 18 i 71 określają dobra osobiste ${ }^{39}$.

Równocześnie nie można przyjąc, w ślad za stanowiskiem Sąu Najwyższego, że stan emocjonalny i psychiczny członka rodziny bezpośrednio poszkodowanego zawsze podlega ochronie prawa cywilnego. System odpowiedzialności odszkodowawczej powinien chronić określone interesy, a jego granice powinny być ściśle oznaczone ${ }^{40}$, co koresponduje zresztą z koncepcja bezprawności względnej ${ }^{41}$. W przypadku uszczerbku na zdrowiu osoby bliskiej należy postawić pytanie o interes, który podlega ochronie, i o granice kompensacji doznanego uszczerbku. Można bowiem przyjąć, że członkowie rodziny poszkodowanego sạjedynie pośrednio poszkodowani, ponieważ zdarzenie nie było skierowane przeciwko nim. Z drugiej strony, jeżeli na skutek zdarzenia szkodzącego (powodującego uszczerbek na zdrowiu członka rodziny) doznają oni naruszenia integralności emocjonalnej czy wstrząsu psychicznego, to są oni bezpośrednio poszkodowani42. W prawie angielskim członkom rodziny poszkodowanego przysługują roszczenia w związku

34. Konstytucja Rzeczypospolitej Polskiej z dnia 2 kwietnia 1997 r. uchwalona przez Zgromadzenie Narodowe w dniu 2 kwietnia 1997 r., przyjęta przez Naród w referendum konstytucyjnym w dniu 25 maja 1997 r., podpisana przez Prezydenta Rzeczypospolitej Polskiej w dniu 16 lipca 1997 r. (Dz. U. 1997 nr 78, poz. 483).

35. Wyrok TK z 10 lipca 2000 r., SK 21/99, 0TK 2000, nr 5, poz. 144.

36. Tak wyrok TK z 10 lipca 2000 r., SK 21/99, OTK 2000, nr 5, poz. 144; 4.5.2004 r., K 8/03, OTK-A 2004, nr 5, poz. 37; tak też w doktrynie L. Garlicki, Artykuł 18, [w:] Konstytucja. Tom III, [red.] K. Działocha, L. Garlicki, P. Sarnecki, W. Sokolewicz, J. Trzciński, Wydawnictwo Sejmowe, Warszawa 2003, uw. 4, s. 2.

37. L. Bosek, op. cit., s. 13.

38. W. Popiołek, op. cit., s. 1046.

39. Wyrok SN z 5 kwietnia 2013 r., sygn. III CSK 198/12; L. Bosek, op. cit., s. 14.

40. M. Wałachowska, Wynagrodzenie szkód..., s. 300; M. Wałachowska, Roszczenie o zadośćuczynienie ..., s. 17; A. Szpunar, 0 ochronie pamięci osoby zmarłej, „Palestra” 1984, nr 7-8, s. 10; P. Księżak, Komentarz do art. 23. [w:] Kodeks cywilny. Część ogólna. Komentarz, [red.] P. Księżak, M. Pyziak-Szafnicka, Wolters Kluwer, Warszawa 2009.

41. Waspekcie materialnym oznacza ona, że granice uszczerbku, jaki podlega kompensacji, uzależnione są od ratio naruszonej normy, która miała chronić przed wystapieniem zagrożenia. Natomiast w aspekcie proceduralnym koncepcja ta oznacza, iż obowiązek odszkodowawczy powstaje jedynie wobec tych podmiotów, które były objęte zakresem ochrony naruszonej normy. Zob. szerzej: Z. Banaszczyk, Glosa do wyroku Sqdu Najwyższego z dnia 24 września 2008 r., II CSK 177/08, „Palestra” 2010, nr 7-8; R. Kasprzyk, Bezprawność względna, „Studia Prawnicze” 1988, z. 3 (97) ], s. 149 i nast.; A. Szpunar, Nadużycie prawa podmiotowego, PAU, Kraków 1947, s. 113.

42. M. Wałachowska, Roszczenie o zadośćuczynienie..., s. 18. 
z bólem, cierpieniem i obniżeniem jakości życia wyłącznie wtedy, gdy sami doznali szkody tj. nieszczęścia doznanego wskutek szkody wyrządzonej osobie, z którą łączy ich więź emocjonalna ${ }^{43}$.

5. Po trzecie, wobec braku wyraźnych granic dobra osobistego w postaci więzi rodzinnej nie jest możliwe wytyczenie kręgu podmiotowego kompensaty szkody. Na pierwszy rzut oka, skoro mowa jest o więzi rodzinnej, należy zastanowić się nad roszczeniami przysługującymi poszczególnym członkom rodziny. Ten sam rodzaj bliskości może bowiem łączyć dziecko z rodzicami, rodzeństwem, jak i z dziadkami, a sama więź rodzinna istnieje także pomiędzy dalszymi krewnymi. Za najbliższych członków rodziny uznać można macochę lub ojczyma ${ }^{44}$ albo dziadków ${ }^{45}$ czy wieloletnich partnerów ${ }^{46}$. Na kanwie dotychczasowego stanowiska doktryny i orzecznictwa trudno wytyczyć granice kompensacji szkody. Co za tym idzie, z tym samym, ewentualnie z takim samym żądaniem może wystapić kilku członków rodziny, zaś rolą sądu orzekającego będzie ocena istnienia więzi rodzinnej i stopnia jej naruszenia. Już w tym miejscu zaznaczenia wymaga, że takie rozwiązanie zachęca do występowania z żądaniem i może przez to prowadzić do „lawiny roszczeń odszkodowawczych"4?. Zauważenia ponadto wymaga, że choć dobro osobiste jest określane jako „więź rodzinna” to jednak roszczenia przyznawane są zwykle osobom najbliższym ${ }^{48}$, co rozszerza kragg osób uprawnionych do dochodzenia roszczeń. Wśród tych uprawnionych mogą znaleźć się nie tylko członkowie rodziny, ale także przyjaciele czy sąsiedzi. Wreszcie, naruszenie więzi rodzinnej pociaga za sobą pokrzywdzenie wszystkich stron tej więzi, w tym również - na co zwrócił uwagę Sąd Najwyższy w glosowanej uchwale - bezpośrednio poszkodowanego. Co za tym idzie, także bezpośrednio poszkodowany może wystapić z żądaniem o zadośćuczynienie w oparciu 0 art. 23 k.c. w zw. z art. 448 k.c., niezależnie od innych, przysługujących mu roszczeń (art. 444 § $1-\S 3$ k.c., art. $445 \S 1-\S 2$ k.c. $^{49}$ ].

Zaznaczyć trzeba, że w ramach kręgu osób legitymowanych do wystapienia z roszczeniem można wyróżnić: zamknięty katalog osób legitymowanych, przyjęty m.in. w Anglii; systemy, w których prawodawca posługuje się jednym pojęciem o charakterze ogólnym tj. „członek rodziny” czy „osoba najbliższa” bądź otwarty krag legitymowanych, każdorazowo określany przez orzecznictwo ${ }^{50}$. Rodzime prawodawstwo przyjęło drugie z zaproponowanych rozwiązań. Można

43. Zob. H. Watson, Zasady i tryb ustalania zadośćuczynienia za ból i cierpienie dla ofiar wypadków drogowych i członków ich rodzin na gruncie prawa angielskiego, [w:] Zadośćuczynienie po nowelizacji art. 446 Kodeksu cywilnego na tle doświadczeń europejskich, [red.] Z. Strus, K. Ortyński, J. Pokrzywniak, PIU, Warszawa 2010, s. 97 i 98.

44. Wyrok z 10 grudnia 1969 r., sygn. III PRN 77/69, Legalis nr 14233.

45. Wyroki SN z 13 kwietnia 2005 r., sygn. IV CK 648/04, Legalis nr 68991; z 10 grudnia 1969 r., sygn. III PRN ?7/69, OSNCP 1970, nr 9, poz. 160.

46. Wyrok SA w Gdańsku w wyroku z 23 grudnia 2014 r., sygn. I ACa 638/14, Legalis nr 1241724.

47. M. Kaliński, Szkoda poniesiona przez spółkę akcyjnq a szkoda poniesiona przez akcjonariusza w świetle przepisów kodeksu spółek handlowych i kodeksu cywilnego - polemika, „Przegląd Prawa Handlowego” 2007, nr 9, s. 53; T. Grzeszak, Dobro osobiste jako dobro zindywidualizowane [w:] Experientia Docet..., s. 919.

48. Tak m.in. uchwała SN z 27 marca 2018 r., sygn. III CZP 60/17, Legalis nr 1781927.

49. Przy czym obecnie, wskutek nowelizacji z 1996 r. normy z art. 445 k.c. i art. 448 k.c. mają odrębne pole zastosowania i pozwalają na zastosowanie jednej z nich. Zob. szerzej: I. Dyka, Zasady przyznawania i ustalania wysokości zadośćuczynienia pieniężnego w razie naruszenia dobra osobistego, „Kwartalnik Prawa Prywatnego" 2001, z. 3, s. 59 ?.

50. M. Wałachowska, Wynagrodzenie szkód... 
postawić tezę, że im bardziej otwarty katalog osób legitymowanych do wystapienia z żądaniem, tym większa jest niepewność prawa, gdyż rozstrzygnięcia są mniej przewidywalne, a co za tym idzie, większe jest obciążenie wymiaru sprawiedliwości.

W judykaturze podkreśla się, że potrzeba zaliczenia więzi rodzinnych do dóbr osobistych podlegających ochronie cywilnoprawnej jest konsekwencja przeświadczenia o trudnym do wyrażenia znaczeniu tej więzi w życiu osoby, która doświadcza życia rodzinnego, ale również równie trudnym do wyrażenia cierpieniu, będącym następstwem zerwania tej więzi, zwłaszcza w sposób nagły, w tym spowodowany przez osoby trzecie ${ }^{51}$. Tymczasem w ramach art. 448 k.c. w zw. z art. 23 k.c. mowa jest o naruszeniu dobra osobistego. Wciąż nie jest jasne, co należy rozumieć przez samo „naruszenie” więzi rodzinnej i jaka jest dystynkcja pomiędzy naruszeniem więzi a jej zerwaniem.

Podkreślenia wymaga, że zmniejszenie jakości życia rodzinnego bądź nieosiągnięcie satysfakcji z poziomu relacji z osobą bliską nie powinno stanowić podstawy dochodzonych roszczeń. Zwłaszcza że niejednokrotnie wraz z uszczerbkiem na zdrowiu osoby bliskiej dochodzi do zacieśnienia stosunków bądź pogłębienia relacji. Czasem relacja może ulec zmianie nie tylko wskutek zdarzeń niezależnych od jej stron ( np. wypadek), ale także wskutek sytuacji zainicjowanych przez jedną ze stron. W przypadku zdrady małżeńskiej również może dojść do zerwania, a co najmniej do osłabienia więzi rodzinnych, a nadto rozstroju zdrowia (objawy emocjonalne, psychiatryczne, motywacyjne czy somatyczne] u pokrzywdzonego ${ }^{52}$. Sprawcą może być zarówno małżonek, jak i osoba trzecia. Zachowanie identyfikujące zdradę może przybierać wiele postaci i - wobec naruszenia przepisów prawa (art. 23 k.r.o.), a nawet zasad współżycia społecznego ${ }^{53}$ - może pozostawać ono bezprawne. Z kolei bezprawność i zawinienie zachowania sprawcy uzasadniaja - przy spełnieniu pozostałych przesłanek odpowiedzialności deliktowej - żądanie zadośćuczynienia pieniężnego za doznaną krzywdę. Orzeczenia w sprawach o zadośćuczynienie z tytułu zdrady małżeńskiej przyznawane są już w Stanach Zjednoczonych Ameryki Północnej ${ }^{54}$.

6. Po czwarte, kontynuując wątek relacyjności więzi rodzinnej, należy zwrócić uwagę na wpływ stosunków majątkowych oraz rodzinnych na żądanie zadośćuczynienia za doznaną krzywdę. W odniesieniu do pierwszych z nich należy postawić w szczególności pytanie, czy nieuiszczanie przez osobę (pośrednio poszkodowanego) świadczeń alimentacyjnych na rzecz członka rodziny (bezpośrednio poszkodowanego) wyłącza dopuszczalność żądania zadośćuczynienia w razie uszczerbku na zdrowiu przez tę osobę bliską. Wobec braku wyraźnego wyłączenia w tym względzie zasadna byłaby analiza wpływu niewywiązywania się z obowiązku alimentacyjnego na jakość więzi rodzinnej, względnie powołanie się na art. 5 k.c.

W odniesieniu natomiast do stosunków rodzinnych należy zastanowić się nad znaczeniem powierzenia sprawowania pieczy nad dzieckiem jednemu z rodziców czy nad władzą rodzicielską i sposobem realizowania kontaktów. Idąc dalej, można postawić pytanie, czy żądanie zadośćuczynienia zostaje wyłączone w razie prawomocnego orzeczenia rozwodu pomiędzy małżonkami. W świetle aktualnego stanowiska prawodawcy, doktryny i judykatury - przy przyjęciu dopuszczalności

51. Wyrok Sądu Apelacyjnego w Warszawie z 10 maja 2018 r., sygn. V ACa 753/17, Legalis nr 1785961.

52. A. S. Tokarz, Zdrada małżeńska. Zadośćuczynienie za zerwanie więzi rodzinnych, „Przegląd Sądowy” kwiecień 2011, s. 113.

53. Wyrok SN z 25 lipca 2003 r., sygn. I PK 330/02, Legalis nr 215296.

54. A. S. Tokarz, op. cit., s. 11 ?. 
kompensowania „szkody pośredniej” doznanej na skutek naruszenia więzi rodzinnej - nie wyłącza to możliwości wystapienia z takim żądaniem. Równocześnie jednak nie można utożsamiać krzywdy z obowiązkiem opieki ciążącym na rodzicach względem dzieci ( $\operatorname{art.} 95$ § 1 k.r.o. ${ }^{55}$ ). Obowiązek wspierania dzieci przez rodziców istnieje od momentu urodzenia się dziecka i nie kończy się automatycznie z chwila uzyskania przez dziecko pełnoletniości. Co oczywiste, obowiązek ten obejmuje psychiczne i moralne wsparcie w cierpieniu, chorobie lub kalectwie - niezależnie od przyczyny ich powstania. Niemniej okoliczność, że życie osoby bliskiej jest zdeterminowane koniecznością sprawowania opieki nad dzieckiem (bezpośrednio poszkodowanym) nie musi prowadzić do przyjęcia, że rozstrój zdrowia pośrednio poszkodowanego pozostaje w związku przyczynowo-skutkowym z pierwotnym zdarzeniem szkodzącym. Odczuwanie pewnych cierpień psychicznych, lęku i dyskomfortu czy poczucia bezradności są niejako wpisane w życie rodzinne. Nie każda niedogodność czy trudność życiowa może stanowić interes podlegający ochronie prawnej. Nieprawidłowe wykonywanie obowiązków rodzinnych może uzasadniać zastosowanie sankcji przewidzianych w prawie rodzinnym, ale nie może stanowić naruszenia dobra osobistego ${ }^{56}$. Podobnie małżonkowie - mają oni równe prawa i obowiązki w małżeństwie, a nadto są obowiązani do wspólnego pożycia, do wzajemnej pomocy i wierności oraz do współdziałania dla dobra rodziny, która przez swój związek założyli (art. 23 k.r.o.).

Na tle powyższego Sąd Najwyższy trafnie zwrócił uwagę, że nawet orzecznictwo i piśmiennictwo ${ }^{57}$, dopuszczając istnienie więzi rodzinnej i kwalifikując ja jako dobro osobiste, podejmuje próbę wytyczenia kryteriów, jakimi należy kierować się przy ocenie naruszenia więzi rodzinnej. Sąd Apelacyjny w Białymstoku w wyroku z 28 lipca 2016 roku uznał, że więź rodzinna jest poddana ochronie na podstawie art. 23 k.c., stanowi szczególne dobro osobiste jednostki z tym zastrzeżeniem, że nie każdą więź rodzinną automatycznie należy zaliczyć do katalogu dóbr osobistych. Dobro osobiste stanowi jedynie taka więź rodzinna, której zerwanie powoduje ból, cierpienie czy rodzi poczucie krzywdy ${ }^{58}$. Stanowisko takie jest szeroko prezentowane w orzecznictwie ${ }^{59}$. Wskazuje się nadto, że nie należy utożsamiać więzi rodzinnej z samym uczuciem przywiązania do osób bliskich $^{60}$, zaś do naruszenia więzi konieczne są na ogół trzy czynniki: wspólne doświadczenie życia rodzinnego, świadomość istnienia tej więzi oraz wola jej zachowania na przyszłośćc1. Wreszcie, nawet Są Najwyższy, podejmując uchwałę z 27 marca 2018 roku ${ }^{62}$, zaakcentował konieczność doznania przez poszkodowanego „ciężkiego” i „trwałego” uszczerbku na zdrowiu, pozostawiając tę ocenę sądowi orzekającemu w sprawie ${ }^{63}$.

55. Ustawa z 25 lutego 1964 r. - Kodeks rodzinny i opiekuńczy, Dz. U. 2017, poz. 682 z późn. zm.

56. L. Bosek, op. cit., s. 11.

57. M. Wałachowska, Roszczenie o zadośćuczynienie..., s. 20.

58. Wyrok SA w Białymstoku z 28 lipca 2016 r., sygn. I ACa 215/16, Lex nr 2112363.

59. Wyrok SA w Krakowie z 8 kwietnia 2016 r., I sygn. ACa 1817/15, Lex nr 2053914; wyrok SA w Krakowie z 13 lutego 2015 r., sygn. I ACa 1671/14, LEX nr 1677083; wyrok SA w Białymstoku z 6 czerwca 2014 r., sygn. I ACa 141/14, Lex nr 1489030; wyrok SA w Łodzi z 10.03.2015 r., I ACa 1359/14, Lex nr 1675898; wyrok SA w Katowicach z 9 marca 2016 r., sygn. I ACa 1099/15, LEX nr 202549 ?.

60. Wyrok SA w Warszawie z 5 września 2017 r., sygn. VI ACa 558/16, Lex nr 2432017.

61. Zob. wyrok SA w Warszawie z 8 stycznia 2016 r., sygn. I ACa 442/15, Lex nr 1979320.

62. Uchwała SN z 27 marca 2018 r., sygn. III CZP 60/17, Legalis nr 1781927.

63. Por. wyrok SN z 9 sierpnia 2016 r., sygn. II CSK 291/16. 
W ocenie autorki nie można także oceniać więzi rodzinnej z perspektywy dobra osobistego w postaci kultu pamięci osoby zmarłej, które obejmuje m.in. uprawnienie osoby bliskiej do pochowania zwłok, ich przeniesienia lub ekshumacji, wybudowania nagrobka i ustalenia napisu na nim, odwiedzania i pielęgnacji grobu, odbywania ceremonii religijnych poświęconych osobie zmarłej. Podstawę naruszenia tego dobra osobistego stanowią konkretne zachowania, które mogą naruszyć ściśle indywidualną sferę uczuciową osoby żyjącej. Stosunek do osoby zmarłej nie dotyczy relacji interpersonalnej ${ }^{64}$. Z pewnością brak w tym przypadku elementu relacyjności, albowiem dobro osobiste należy oceniać - co oczywiste - wyłącznie z perspektywy osoby bliskiej (będącej wówczas bezpośrednio poszkodowanym]. Stanowi indywidualną, ściśle związaną z jednostką ludzką, niemajątkową wartość, której naruszenie powoduje ból i cierpienie.

7. W dalszej kolejności trzeba dostrzec wpływ problematyki tzw. „szkody pośredniej” na gałąź ubezpieczeń gospodarczych. Rozszerzenie granic kompensacji szkody będzie wymuszać oferowanie nowych produktów ubezpieczeniowych oraz wzrost składek ubezpieczeniowych, a być może także rozszerzenie zakresu ubezpieczeń obowiązkowych. Skoro ubezpieczyciel ponosi odpowiedzialność w razie śmierci ofiary wypadku - nawet gdy do wypadku doszło w czasie, gdy z orzecznictwa nie wynikała możliwość dochodzenia roszczenia o zadośćuczynienie - to brak jest podstaw, aby nie przypisać jej w razie uszczerbku na zdrowiu osoby bliskiej ${ }^{65}$. Co ważne, w sytuacji objętej przepisem art. 106 ustawy o ubezpieczeniach obowiązkowych ${ }^{66}$ nie przewidziano ochrony osób pośrednio poszkodowanych ${ }^{6}$.

Nie bez znaczenia dla rozwoju ubezpieczeń pozostaje taryfikacja i standaryzacja świadczeń odszkodowawczych ${ }^{68}$, zwłaszcza, że zadośćuczynienie powinno być „odpowiednie”, uwzględniajace rozmiar i rodzaj szkody niemajatkowej69. Obecnie w orzecznictwie proponuje się, aby ustalanie wysokości zadośćuczynienia pieniężnego za doznaną krzywdę pociaggało za sobą ich przyznawanie w podobnej wysokości w zbliżonych, analogicznych przypadkach?o . Jak podnosi się

64. L. Bosek, W sprawie kwalifikacji więzi rodzinnej jako dobra osobistego (uwagi krytyczne na tle aktualnego orzecznictwa Sqdu Najwyższego], Forum Prawnicze 2015, s. 12.

65. Uchwała SN z 7 listopada 2012 r., sygn. III CZP 67/12, Legalis nr 544320. Zob. także: K. Osajda, Zadośćuczynienie na doznanie przez bliskiego uszczerbku na zdrowiu wskutek wypadku, „Państwo i Prawo” 2016, nr 1, s. 83-84.

66. Ustawa z dnia 22 maja 2003 r. o ubezpieczeniach obowiązkowych, Ubezpieczeniowym Funduszu Gwarancyjnym i Polskim Biurze Ubezpieczycieli Komunikacyjnych (Dz. U. 2003 nr 124, poz. 1152).

67. M. Wałachowska, Wyłqczenie odpowiedzialności UFG za szkody wyrzqdzone posiadaczowi pojazdu mechanicznego przez kierujacego nieubezpieczonym pojazdem a roszczenia osób pośrednio poszkodowanych, „Prawo Asekuracyjne” 2016, nr 4, s. 15.

68. W prawie angielskim członkom rodziny poszkodowanego przyznawane jest zadośćuczynienie pieniężne w związku z bólem, cierpieniem i obniżeniem jakości życia w zryczałtowanej kwocie 15,120 GBP. Zob. H. Watson, op. cit., s. 97 i 98.

69. Górne limity odszkodowań istnieją w Holandii, Portugalii i Wielkiej Brytanii. W innych państwach, w tym w Belgii, we Włoszech, w Hiszpanii i Norwegii, przygotowywane są tabele z przykładowymi, jednak niewiążącymi sąd orzekający kwotami zadośćuczynienia. Zob. także: M. Wałachowska, Zadośćuczynienie pieniężne a odsetki w świetle orzecznictwa sqdowego i doktryny, „Prawo Asekuracyjne” 2016, nr 2, s. 4 ? i nast.; E. Bagińska, Kompensacja krzywdy osób najbliższych w razie poniesienia przez poszkodowanego ciężkiego uszczerbku na zdrowiu - przeglaqd rozwiqzań europejskich, [w:] Rozprawy z prawa prywatnego. Księga jubileuszowa dedykowana Profesorowi Wojciechowi Popiołkowi..., s. 640.

70. Wyrok SN z 1 września 1967 r., sygn. II PR 318/6?, Legalis nr 13189; I. Dyka, op. cit., s. 616. 
w orzecznictwie, postulat sprawiedliwości pozostaje spełniony jeżeli przyznane zadośćuczynienie pieniężne nie pozostaje w znacznej dysproporcji do kwot przyznawanych w podobnej sytuacji innym poszkodowanym, przy uwzględnieniu oceny okoliczności in casu przeprowadzonej przez Sąd ${ }^{71}$. Tymczasem w praktyce trudno zrealizować te postulaty, czego dowodzi rozbieżne orzecznictwo?2.

Przy określaniu wysokości zadośćuczynienia praktyka podkreśla konieczność uwzględnienia wszystkich okoliczności krzywdy, w tym rodzaju i stopnia winy sprawcy, a nawet jego zachowania po popełnieniu czynu ${ }^{73}$. Wśród kryteriów posiłkowych przyjmowanych w orzecznictwie można wymienić takie jak: konieczność zapewnienia ekonomicznie odczuwalnej wartości ${ }^{74}$, trwałość

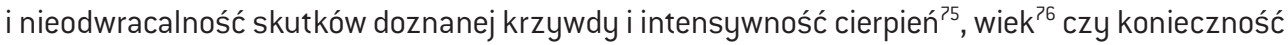
korzystania z pomocy innych osób przy prostszych czynnościach życia codziennego?? W przypadku naruszenia dóbr osobistych ustalenie wysokości zadośćuczynienia powinno nastapić z uwzględnieniem dobra osobistego, do którego naruszenia doszło ${ }^{78}$. Niewątpliwie jednak uznanie więzi rodzinnych za dobro osobiste doprowadzi do wzrostu składek ubezpieczeniowych i nierentowności rynku ubezpieczeń OC pojazdów mechanicznych ${ }^{79}$.

Kryteria wskazywane w doktrynie i judykaturze z jednej strony pozostają nieprecyzyjne i pozostawiają dość dużą swobodę sądowi orzekającemu, z drugiej zaś pozwalają na uwzględnienie indywidualnych okoliczności pozostających w związku z osoba poszkodowanego, zaistniała sytuacją i funkcją, jaką zadośćuczynienie ma realizować. Co prawda zadośćuczynienie pełni funkcję kompensacyjną ${ }^{80}$, jednak odszkodowawcza odpowiedzialność sprawcza realizuje również funkcję

71. Wyrok SN z 29 maja 2008 r., sygn. II CSK 78/08, LEX nr 420389.

72. W przypadku zadośćuczynienia za śmierć osoby bliskiej, tj. ojca, zob. wyrok SA w Krakowie z 23 listopada 2012 r., sygn. I ACa 1083/12, Legalis nr 721938 - 50000 zł; wyrok SO w Kielcach z 9 stycznia 2014 r., sygn. II Ca 1490/13, Legalis nr 2047282 - 20000 zł; wyrok S0 w Gliwicach z 22 sierpnia 2014 r. sygn. III Ca 534/14, Legalis nr 2030932 - 10000 zł; wyrok S0 w Nowym Sączu z 8 października 2014 r., sygn. III Ca 424/14, Legalis nr 2053051 -15 000 zł; wyrok SR w Myszkowie z 12 maja 2015 r., sygn. I C 3/15, Legalis nr 2030222 6000 zł 4000 zł; wyrok SA we Wrocławiu z 8 lipca 2015 r., sygn. I ACa 584/15, Legalis nr 1508957 - 20000 zł; wyrok SR w Gliwicach z 30 grudnia 2015 r., sygn. I C 2000/14, Legalis nr 2044754 - 25000 zł; wyrok SO Warszawa - Praga w Warszawie z 29 stycznia 2016 r., sygn. II C 298/15, Legalis nr 2139993 - 50000 zł; wyrok SR w Gliwicach z 14 czerwca 2016 r., sygn. IC 76/16, Legalis nr 2042640 - 17500 zł; wyrok SR w Krośnie z 13 września 2016 r., sygn. I C 1554/14, Legalis nr 2118759 - 15000 zł; wyrok SO w Warszawie z 23 września 2016 r. sygn. I C 1352/15, Legalis nr 2126225 - 80000 zł;

73. Z. Strus, Zadośćuczynienie w razie śmierci osoby bliskiej [w:] Zadośćuczynienie po nowelizacji art. 446 Kodeksu cywilnego na tle doświadczeń europejskich, red. Z. Strus, K. Ortyński, J. Pokrzywniak, PIU, Warszawa 2010, s. 30; wyrok SN z 12 września 2002 r., sygn. IV CKN 1266/00, LEX nr 80272; wyrok SN z 9 stycznia 1978 r., sygn. IV CR 510/7?, Legalis nr 20611.

74. Wyrok SA w Warszawie z 10 kwietnia 2008 r., sygn. VI ACa 1248/07, LexPolonica nr 1960175.

75. Wyrok SA w Katowicach z 3 listopada 1994 r., sygn. III APr 43/94, OSA 1995, z. 5, poz. 41; wyrok SN z 28 czerwca 2005 r., sygn. I CK $7 / 05$, LEX nr 153254.

76. Wyrok SA w Katowicach z 17 kwietnia 2014 roku, sygn. V ACa 836/13, LEX nr 1461044.

77. Wyrok SA w Łodzi z 26 lutego 1998 r., sygn. I ACa 39/98, Legalis nr 41839.

78. Zob. I. Dyka, op. cit., s. 623 i nast.

79. W. Popiołek, op. cit., s. 1056; B. Lanckoroński, op. cit., s. 193.

80. M. Syska, Wysokość zasqdzonego odszkodowania oraz tzw. punitive damages a klauzula porzqdku publicznego w postępowaniu o stwierdzenie wykonalności orzeczenia zagranicznego, „Przegląd Sądowy” 2015, s. 53 inast. 
prewencyjną, a w ograniczonym zakresie - także penalną ${ }^{81}$. Funkcja kompensacyjna może również ewoluować bądź występować wraz z czynnikiem represyjno-wychowawczym ${ }^{82}$. Mając to na uwadze, należy zweryfikować, czy katalogowanie i klasyfikowanie występujących w sprawach powtarzalnych okoliczności oraz przedstawianie ich w wiarygodnych zestawieniach pozwoli uniknąć opartych na intuicji wysokości roszczeń stron, a niejednokrotnie - także rozstrzygnięć. W ocenie autorki orzecznictwo powinno kierować się jednolitą skalą wartości podstawowych, które usprawiedliwiają i uzasadniają aksjologicznie roszczenia o zadośćuczynienie. Dażenie zatem do ujednolicania wysokości świadczeń w podobnych wypadkach, przy pozostawieniu sądowi orzekającemu w sprawie pewnej swobody, nie powinno być postrzegane jako zagrożenie prawa do sądu albo niezawisłości sądu. To właśnie postulat równości wobec prawa i sprawiedliwości nakazuje jednakowe traktowanie osób znajdujacych się w podobnej sytuacji ${ }^{83}$.W rzeczywistości chodziłoby o wiarygodność rozstrzygnięć co do wysokości świadczeń przyznawanych za krzywdy doznane w pewnych powtarzalnych sytuacjach, co pozwoliłoby na uniknięcie niepewności, racjonalizowanie postępowania i dążenie do uniknięcia zbędnych i nadmiernych kosztów, trudów i napięć związanych z ewentualnym procesem ${ }^{84}$.

Zagadnienie szkody pośredniej z perspektywy ubezpieczeń gospodarczych zostało także dostrzeżone w orzecznictwie sądów europejskich, co jedynie podkreśla, jak ważka jest to problematyka. TS, rozważając przyznanie zadośćuczynienia w ramach obowiązkowego ubezpieczenia od odpowiedzialności cywilnej wynikającej z ruchu pojazdów mechanicznych za szkodę spowodowaną zgonem bliskiej osoby w wypadku drogowym, uznał, że ubezpieczenie obowiązkowe odpowiedzialności cywilnej obejmuje zadośćuczynienie za szkody niematerialne poniesione przez bliskich poszkodowanych, którzy zmarli w wypadku drogowym w takich okolicznościach, o ile to zadośćuczynienie jest przewidziane z tytułu odpowiedzialności cywilnej ubezpieczonego przez właściwe dla sporu prawo krajowe ${ }^{85}$.

8. W świetle powyżej przedstawionych rozważań uznać trzeba, że zagadnienie „szkody pośredniej" stanowi obecnie wyzwanie dla wszystkich jurysdykcji, w których przyjęto odpowiedzialność odszkodowawcza. Przy wyborze środka kompensacyjnego należy bowiem uwzględnić utrwalone w społeczeństwie poglady moralne i etyczne, dostrzegając także negatywne skutki merkantylizacji interesów i dóbr osobistych. Ta analiza pozwoli na określenie minimalnych wymagań stawianych systemowi prawnemu. Szczególne znaczenie ma w prawie polskim, w którym jej kompensowanie

81. Wyrok SN z 13 stycznia 2012 r., sygn. I CSK 790/10, LEX nr 3026184; M. Kaliński, [w:] System Prawa Prywatnego. Tom 6. Prawo zobowiqzań - część ogólna, [red.] A. Olejniczak, CH Beck, Warszawa 2009, s. 69; uchwała SN z 19 czerwca 2007 r., sygn. III CZP 54/07, Legalis nr 83245.

82. Wyrok SN z 15 lipca 1977 r., sygn. IV CR 263/7?, Legalis nr 20231; A. Szpunar, 0 zakresie odpowiedzialności za szkodę na osobie, „Nowe Prawo” 1974, nr 12, poz. 1633; uchwała SN z 8 grudnia 1973 r., sygn. III CZP 37/73, Legalis $\mathrm{nr} 17569$.

83. Z. Strus, op. cit., s. 28.

84. Obok taryfikacji postuluje się wprowadzenie normatywnego obowiązku konsultowania przez zakłady ubezpieczeń wysokości świadczeń przekraczających pewną kwotę uznaną i wypłaconą niezwłocznie po ustaleniu okoliczności zdarzenia. Zob. szerzej: Z. Strus, op. cit., s. 29.

85. Zob. opinia Rzecznika Generalnego przedstawiona w dniu 11 lipca 2013 r. w sprawie Katarína Haasová przeciwko Rastislavowi Petríkowi,Blance Holingovej, C-22/12 oraz w sprawie Vitālijs Drozdovs przeciwko AAS Baltikums C-27?/12, EUR-LEx nr 62012CC0022. 
następuje przez sięgnięcie do klauzul generalnych albo przepisów ogólnych. Niedostatki tego rozwiązania zostały dostrzeżone przez prawodawcę, który w 2008 r. wprowadził szczególną podstawę przyznania zadośćuczynienia pośrednio poszkodowanym w postaci art. $446 \S 4$ k.c., ale wyłącznie w przypadku śmierci osoby bliskiej. Aktualny stan prawny stanowi próbę pogodzenia black letter law z interesem prywatnym. Można zaaprobować ograniczenie przyznawania zadośćuczynienia z tytułu uszczerbku na zdrowiu osoby bliskiej do sytuacji, w których poszkodowany znajduje się w stanie wegetatywnym. Przy czym wymaga to interwencji prawodawcy. Trzeba bowiem pamiętać, że zbyt duża dowolność w interpretacji przepisów prawa będzie prowadzić do zastępowania albo marginalizowania roli prawodawcy. W ocenie autorki, nawet jeżeli jego decyzje są niepopularne i trudne, to powinny realizować podstawową zasadę prawa cywilnego, zgodnie z którą kompensacja szkody pośredniej stanowi wyjatek, stosowany w ściśle oznaczonych sytuacjach. W innym wypadku stanie się reguła, a instytucje prawne będą wykorzystywane do innych celów niż zostały powołane - tak jak dzieje się to w przypadku roszczeń z tytułu naruszenia więzi rodzinnej.

\section{Wykaz źródeł}

Bagińska E., Dopuszczalność dochodzenia przez osoby bliskie zadośćuczynienia w zwiqzku z doznaniem poważnej szkody na osobie przez bezpośrednio poszkodowanego, „lustitia” 2016, nr 2. Bagińska E., Kompensacja krzywdy osób najbliższych w razie poniesienia przez poszkodowanego ciężkiego uszczerbku na zdrowiu - przeglad rozwiqzań europejskich, [w:] Rozprawy z prawa prywatnego. Księga jubileuszowa dedykowana Profesorowi Wojciechowi Popiołkowi, Jagielska M., Pazdan M., Rott-Pietrzyk E., Szpunar M. [red.], Wolters Kluwer, Warszawa 2017.

Banaszczyk Z., Glosa do wyroku Sqdu Najwyższego z dnia 24 września 2008 r., II CSK 177/08, „Palestra” 2010, nr 7-8.

Bosek L., W sprawie kwalifikacji więzi rodzinnej jako dobra osobistego (uwagi krytyczne na tle aktualnego orzecznictwa Sadu Najwyższego), „Forum Prawnicze” 2015.

Dyka l., Zasady przyznawania i ustalania wysokości zadośćuczynienia pieniężnego w razie naruszenia dobra osobistego, „Kwartalnik Prawa Prywatnego” 2001, z. 3.

Garlicki L., Artykuł 18, [w:] Konstytucja. Tom III, Działocha K., Garlicki L., Sarnecki P., Sokolewicz W., Trzciński J. [red.], Wydawnictwo Sejmowe, Warszawa 2003.

Gaska M., Więź rodzinna - refleksje nad charakterem dobra oraz dopuszczalnościq i sposobami kompensacji krzywdy wywołanej jego naruszeniem, „Forum Prawnicze” 2018.

Grzeszak T., Dobro osobiste jako dobro zindywidualizowane, [w:] Experientia Docet. Księga jubileuszowa ofiarowana Pani Profesor Elżbiecie Traple, Kostański P., Podrecki P., Targosz T. [red.], Wolters Kluwer, Warszawa 201?.

Kaliński M., [w:] System Prawa Prywatnego. Tom 6. Prawo zobowiqzań - część ogólna, Olejniczak A. [red.], CH Beck, Warszawa 2009.

Kaliński M., Szkoda poniesiona przez spółkę akcyjnq a szkoda poniesiona przez akcjonariusza w świetle przepisów kodeksu spółek handlowych i kodeksu cywilnego - polemika, Przeglad Prawa Handlowego 2007 nr 9.

Kasprzyk R., Bezprawność względna, „Studia Prawnicze” 1988, z.3(97).

Księżak P., Komentarz do art. 23, [w:] Kodeks cywilny. Część ogólna. Komentarz, Księżak P., PyziakSzafnicka M. [red.], Wolters Kluwer, Warszawa 2009. 
Lanckoroński B., Kontrowersje wokół ustalania odpowiedzialności z tytułu naruszenia więzi rodzinnych jako dobra osobistego, „Studia Prawnoustrojowe” 2019, nr 46.

Matys 0., Kontrowersje wokół podstaw i przesłanek zadośćuczynienia na rzecz najbliższych osób zmarłego, „Administracja Publiczna. Studia krajowe i międzynarodowe. Zeszyty Naukowe WSAP w Białymstoku" 2006, nr 1.

Opinia Rzecznika Generalnego przedstawiona w dniu 11 lipca 2013 r. w sprawie Katarína Haasová przeciwko Rastislavowi Petríkowi,Blance Holingovej, C-22/12 oraz w sprawie Vitālijs Drozdovs przeciwko AAS Baltikums C-27?/12, EUR-LEx nr 62012CC0022.

Orlicki M., 0 możliwości dochodzenia roszczeń o zadośćuczynienie za śmierć najbliższego członka rodziny zmarłego przed dniem 3 sierpnia 2018 r., „Prawo Asekuracyjne” 2013, nr 4.

Osajda K., Zadośćuczynienie za doznanie przez bliskiego uszczerbku na zdrowiu wskutek wypadku, „Państwo i Prawo” 2016, nr 1.

Owczarek M., Problem bezprawności względnej w systemie odpowiedzialności deliktowej, „Palestra” 2004, nr 5-6(557-558).

Popiołek W., Więź między osobami fizycznymi jako przedmiot ochrony cywilnoprawnej, [w:] Experientia Docet. Księga jubileuszowa ofiarowana Pani Profesor Elżbiecie Traple red. P. Kostański, P. Podrecki, T. Targosz, Wolters Kluwer, Warszawa 201 ?.

Sadomski J., Wild M., Zadośćuczynienie za śmierć osoby najbliższej w orzecznictwie sqdów powszechnych, „Prawo w Działaniu. Sprawy Cywilne” 2012, nr 12.

Strus Z., Zadośćuczynienie w razie śmierci osoby bliskiej, [w:] Zadośćuczynienie po nowelizacji art. 446 Kodeksu cywilnego na tle doświadczeń europejskich, Strus Z., Ortyński K., Pokrzywniak J. [red.], PIU, Warszawa 2010.

Syska M., Wysokość zasqdzonego odszkodowania oraz tzw. punitive damages a klauzula porzadku publicznego w postępowaniu o stwierdzenie wykonalności orzeczenia zagranicznego, „Przeglad Sądowy” 2015.

Szpunar A., Nadużycie prawa podmiotowego, PAU, Kraków 1947.

Szpunar A., 0 ochronie pamięci osoby zmarłej, „Palestra” 1984, nr 7-8.

Szpunar A., O zakresie odpowiedzialności za szkodę na osobie, „Nowe Prawo” 1974, nr 12, poz. 1633.

Tokarz A. S., Zdrada małżeńska. Zadośćuczynienie za zerwanie więzi rodzinnych, „Przeglad Sąowy, kwiecień 2011.

Wałachowska M., Glosa do wyroku Sqdu Najwyższego z 14.01.2010 r., IV CSK 307/09, „Orzecznictwo Sądów Polskich" 2011, nr 2, poz. 15.

Wałachowska M., Roszczenie o zadośćuczynienie pieniężne za zerwanie więzi rodzinnych w razie doznania przez osobę bliska poważnego uszczerbku na zdrowiu, „Przegląd Sądowy” 2017, nr 9.

Wałachowska M., Wyłaczenie odpowiedzialności UFG za szkody wyrzqdzone posiadaczowi pojazdu mechanicznego przez kierujacego nieubezpieczonym pojazdem a roszczenia osób pośrednio poszkodowanych, „Prawo Asekuracyjne” 2016, nr 4.

Wałachowska M., Wynagrodzenie szkód deliktowych doznanych przez pośrednio poszkodowanych, Wolters Kluwer, Warszawa 2014.

Watson H., Zasady i tryb ustalania zadośćuczynienia za ból i cierpienie dla ofiar wypadków drogowych i członków ich rodzin na gruncie prawa angielskiego, [w:] Zadośćuczynienie po nowelizacji art. 446 Kodeksu cywilnego na tle doświadczeń europejskich, Strus Z., Ortyński K., Pokrzywniak J. [red.], PIU, Warszawa 2010. 
Wniosek Rzecznika Finansowego z 13.12.2019 r., https://rf.gov.pl/pdf/SN_wniosek_stany_wegetatywne.pdf [dostęp: 4.09.2020].

http://www2.gov.si/zak/Zak_vel.nsf/7e8891d494d7669fc1256616002db47b/c12563a4003388 36c1256adb002917dd?OpenDocument [dostęp: 20.08.2020].

\section{Commentary of the Composition of Five Judges of the Supreme Court, Chamber of Extraordinary Supervision and Public Cases, $22^{\text {nd }}$ October 2019, I NSNZP 2/19}

The hereby commentary is an attempt of analysis of limitations of liability in connection with judgment of Supreme Court of 22.10.2019 (I NSNZP 2/19). It should also be noted that it is problematic to delimit circle of people, who in principle could be entitled to compensation. Consequently, it may be difficult to appoint liability, when victim - after accident - is alive, but he/she has serious damage on his/her health. The Supreme Court assumed that closest family members aren't entitled to claim damages for mental harm in case of infringement of family ties due to a direct injury to the victim. In opinion of the Supreme Court, a family relationship cannot be qualified as a personal interest because of its interpersonal nature. The Polish Civil Code contains exemplary catalogue (article 23rd) and means of protection (article 24th] but it doesn't mean that subjective family bonds will be protect. Finally, dissatisfaction with family life doesn't justify granting damages for non-pecuniary loss. What is more, judgment of Supreme Court of 22.10.2019 is incompatible with judgment of Supreme Court of 27.03.2018.

Keywords: personal rights, indirect damage, family tie, limitations of liability, non-pecuniary losses.

ANETA PALECZNA - doktorantka w Instytucie Nauk Prawnych, Prawo Cywilne i Prawo Prywatne Międzynarodowe Uniwersytetu Ślaskiego w Katowicach, aplikantka adwokacka przy ORA w Katowicach. nr ORCID: 0000-0001-7951-200 
